\title{
A városi útburkolat-gazdálkodás sajátosságai
}

Az útburkolat-gazdálkodási rendszer (PMS) a hálózat egyes lehetséges projektjeit hosszú távú gazdaságosságuk szerint sorolja. 2018-ban a KTI az elsőként kidolgozott PMS-t továbbfejlesztette, amelynek elemei: a kétszintü önkormányzati rendszer okozta nehézségek; a burkolat-állapotparaméterek jelentősége települési utakon; a pályaszerkezet-méretezési eljárások városi korlátai; etalonszakaszok kiválasztása, a homogén szakaszok meghatározásának elve.

DOI 10.24228/KTSZ.2020.2.2

\section{Dr. habil. Gáspár László - Pusztai Gábor}

okl. mérnök, okl. gazdasági mérnök, az MTA doktora, a KTI Közlekedéstudományi Intézet Nonprofit Kft. kutató professzora, a Széchenyi István Egyetem emeritusz professzora e-mail: gaspar@kti.hu, okl. múszaki térinformatikus, okl. építőmérnök, nyilvántartási osztályvezető Budapest Közút Zrt.

gabor.pusztai@budapestkozut.hu

\section{BEVEZETÉS, CÉLKITÜZÉS}

Az utak kezelői a városi hálózatokon számos, a külsőségi szakaszokétól eltérő gazdálkodási problémával kerülnek szembe. Ebből adódóan, azok útburkolat-gazdálkodási rendszere (PMS-e) is többé-kevésbé eltér egymástól. A városi útburkolat-gazdálkodás sajátosságait a következőkben, esettanulmányként, a főváros számára készült PMS egyes elemeinek rövid ismertetésével szemléltetjük.

2010-ben a Közlekedéstudományi Intézet Nonprofit Kft. (KTI) a Fővárosi Közterületfenntartó Vállalat Zrt. (a Budapest Közút Zrt. jogelődje) számára, az általa kezelt fóvárosi fớthálózatra vonatkozóan, útburkolat-gazdálkodási rendszer (PMS) első változatát készítette el [1]. Az összeállítása időpontjában rendelkezésre álló információk és összefüg- gések számítógépes modell kidolgozásához is alapul szolgáltak [2].

Ez a hálózati és a létesítményi szint közötti, ún. program szintű útburkolat-gazdálkodási rendszer az érintett hálózat - Budapest főváros fouthálózata, valamint annak közösségi közlekedéssel érintett mellékúthálózata - egyes lehetséges projektjeit hosszú távú gazdaságosságuk szerint sorolja.

A PMS-nek ebben a kidolgozási fázisában a kiinduló adatok (inputok) csak korlátozott mértékben álltak rendelkezésre, valamint, ebből is következően, a rendszer „lényegét” képező algoritmusok és összefüggések általában még nem alapulhattak tényleges, helyi adatokon. Ezért számítani lehetett arra, hogy ez az ideiglenes modell viszonylag rövid időn belül továbbfejlesztésre szorul, amelyhez az 


\section{Közúti közlekedés}

érdekelt szakemberek bírálata [3-5], kisebb hálózatrészen végzett futtatás eredményeinek értékelése, valamint a teljes hálózatrészre vonatkozó, leltár jellegü, állapot, forgalmi, gazdasági stb. alapinformációk további beszerzése [6], illetve az egész modell futtatása [7-9] nyújt lehetőséget.

A Budapest Közút Zrt. 2018-ban a KTI-vel, az első PMS változat kidolgozójával olyan szerződést kötött, amely az útburkolat-gazdálkodási rendszer időközben végzett módosításaival, kiegészítéseivel elért pillanatnyi helyzet áttekintését és a tárgykörben, javító szándékú javaslatok készítését tűzte ki céljául [10].

A következőkben - részben a [10] kutatási jelentésre támaszkodva - a városi útburkolatgazdálkodási rendszerrel, kiemelten annak sajátosságaival foglalkozunk.

\section{ELÖZMÉNYEK}

Bár kiindulási alapként a KTI és alvállalkozójának 2010-es jelentéseit [1-2] tekintették, 2018ban a Vállalkozó (KTI) feladatai között volt a Megbízó (Budapest Közút Zrt.) által számára átadott előzményanyagok [3-9] megismerése, illetve a bennük levő futtatási eredmények, valamint az anyagokban szereplö továbbfejlesztési javaslatok és fejlesztési irányok értékelése is. Ezek közül a három elözményanyagra a jelentés [10] különleges figyelmet fordított. Jelen cikk előzményeként, az ezekben felvetett egyes kérdéseket és az azokra megfogalmazott válaszokat foglaltuk össze.

Felmerült az, hogy az országos és a budapesti közúthálózat igénybevételi eltéréseinek tekintetbevételével, az országos közúthálózatból kijelölt 60 db etalonszakasznak a KTI által már 28 éve megfigyelt leromlási jellemzőinek általánosítása [11] a fővárosi útburkolat-gazdálkodás kidolgozásakor hasznosítható-e. Amíg a fövárosi etalonszakaszok teljesítményi adatsora még nem áll rendelkezésre, addig a legjobb kompromisszumnak az országos közutakon kijelölt etalonszakaszok hosszú távú állapotmegfigyelésén nyugvó, hálózatviselkedési modellek tekinthetők.
A pályaszerkezet-teherbírás nagyon gyakran a mértékadó állapotparaméter, azaz a felújítás kiváltójává (indokává) ennek a paraméternek a már elfogadhatatlanul gyenge volta válik. Sajnálatos tény azonban, hogy ennek az állapotparaméternek a hálózatviselkedési modelljei, az említett hosszú távú etalonszakasz-megfigyelés eredményeinek feldolgozása alapján, gyakorlatilag nem voltak előállíthatók, mert a teherbírást jellemző E-modulus értéke az idő, illetve a lefutott forgalom függvényében egyértelmű tendenciát nem mutatott [11]. Megjegyzésre érdemes, hogy a KTI témafelelösének bevonásával, jelenleg folyik olyan kutatási munka [12], amely ennek a helyzetnek a javítását, esetlegesen a probléma feloldását tüzte ki céljául. Az országos közúthálózatból választott etalonszakaszokon dinamikus alapelvű, KUAB-típusú, ejtősúlyos berendezés 25 m-enként meghatározott teherbírásmérési értékeit hasznosítják. Ugyanakkor Budapesten kvázi-statikus eljárást követve, Lacroixmérőkocsival mérnek, amely 3-4 m-enként szolgáltat behajlási adatokat. Itt az lehet a kompromisszumos megoldás, hogy a már több éve folyó pályabehajlási idősorokat felhasználva, mihamarabb olyan teherbírási, hálózatviselkedési modelleket fejlesszenek ki, amelyek a Budapest Közút Zrt. PMS-ének első változatában, érdemleges előzmények hiányában felvett modelleket helyettesíthetik.

Szóba jött az is, hogy a teherbírási modellek köre nem túlságosan leegyszerüsített-e, mivel csak a kötött és a szemcsés altalaj szerint különböztet meg, illetve csupán két pályaszerkezet-típussal operál. Nyolc évvel ezelőtt, a PMS első változatának készítési időpontjában, a $1000 \mathrm{~km}$-es összes hosszúságú fővárosi úthálózatról csak nagyon hézagos pályaszerkezeti információk álltak rendelkezésre. Ez indokolta a négy jellemző pályaszerkezettípus felvételét. Ez az osztályozás az időközben gyüjtött sok pályaszerkezeti információ hasznosításával, akár már továbbfejleszthető, reálisabbá tehető. A hálózati szintű PMS számára, a földművek kötött és szemcsés talajú változatokba történő osztályozása elegendőnek ítélhető. Hajlékony, félmerev, merev és kompozit pályaszerkezettípusok megkülönböztetése javasolható. 


\section{Közúti közlekedés}

Közismert, hogy külföldön már vannak müködő, városi PMS-ek. Hazai adaptációjukat azonban az eltéröen rendelkezésre álló inputok és az anyagi lehetőségek által is meghatározott beavatkozási határokban meglevő jelentős különbségek határozottan megnehezítik. Ismereteink szerint, hazai városi PMS egyedül Győr városára született, 1993-ban (a KTI vezetésével dolgozó munkacsoport készítette [13]). Ennek alapelvéböl a Budapest Közút Zrt. számára készülő rendszer sokat hasznosított.

$\mathrm{Az}$ útburkolat-gazdálkodási rendszer fontos elemének, az életciklusköltségek számításakor, a szóban forgó útszakaszon lebonyolódó személy- és teherforgalom mértékét külön kell kezelni. Ennek ugyan elsősorban a különböző úthasználói költségtípusok (közlekedésüzemi költség, időveszteség-költség és baleseti költség) meghatározásakor van jelentősége, de az életciklusköltségek az egyes burkolatállapotparaméterek beavatkozási határára is különbözőképpen hatnak. Erre a célra a Budapesti Közlekedési Központ (BKK) hurokdetektoros forgalmi adatai is hasznosak lehetnek. Ez a továbbfejlesztés viszonylag sok adatgyüjtéssel és többletenergia-ráfordítással jár, ami a hálózati szintű PMS-vizsgálatok során nem „fizetődik ki”. A közeljövőre tervezett létesítményi szintű változat megfelelő minőségű müködéséhez azonban egyértelmüen indokolt a vizsgált útszakaszon lebonyolódó személy- és teherforgalom mértékét külön kezelni.

A városi úthálózat gazdálkodása, illetve a projekt-képző homogén szakaszok szempontjából fontos az esetenként akár mértékadóvá váló állapotparaméterek kialakítása, mint az országos kezelésü közutakon. A homogén szakaszok képzésére a Budapest Közút Zrt. megbízásából készített 2018-as KTI-tanulmány [11] újszerü javaslattal él. A pályaszerkezet-teherbírás, mint állapotparaméter jelentősége a települések útjain sem vitatható; ez tekinthető, a felületépséggel együtt, a leglényegesebb paraméternek. Ugyanakkor a PMS most folyó, létesítményi (projekt) szintű továbbfejlesztésekor a teherbírás mértékadó évszakban mérhető értéke még nagyobb szerephez jut. Emellett, természetesen, a hossz- és a keresztirányú felületi egyenetlenség, valamint a csúszásellen- állás sem hagyható figyelmen kívül, még ha a kisebb városi jármüsebességek között, jelentőségük, az országos közúthálózatéhoz képest, némileg csökken.

A 2018-ban továbbfejlesztett modell [10] foglalkozik az egyes mért burkolatállapot-szintek állapotosztályzatokba történő átszámításának kérdésével. Az osztályozási határértékekre úttípustól függő határértékeket javasol, amelyeknek meghatározásakor, a korábban kapott mérési eredmények statisztikai feldolgozása is komoly segítséget nyújtott.

\section{A KÉTSZINTÜ ÖNKORMÁNYZA- TI RENDSZER OKOZTA NEHÉZ- SÉGEK}

Az országos közúthálózat kezelése és üzemeltetése 2013. november 1. óta a Magyar Közút NZrt.-nél összpontosul, viszonylag egyértelművé téve a felelősségi köröket és határokat. A települési utak tekintetében azonban a helyzet bonyolultabb. Az átkelési szakaszok kezelöje továbbra is a Magyar Közút NZrt., de a csatlakozó települési utak kezelési feladatait a helyi önkormányzat látja el. Itt már megjelenik a két közútkezelő közötti határok tisztázásának igénye, ugyanis a tulajdonosi határok nem feltétlenül esnek egybe a müszakilag optimális kezelői határokkal. Ezt a nehézséget tovább fokozza, hogy egyedüliként az országban, Budapesten kétszintü önkormányzati rendszer müködik, így a települési utak kezelése is kétszintüvé vált. A vonatkozó Kormányrendelet [13] hatályba lépésével a fővárosban a kezelöi határok részben elváltak a tulajdonosi határoktól. A rendelet értelmében, a kezelö szervezet három szempont alapján dől el. A vonatkozó törvény [14] alapján, a helyi közutak kezelöje általános esetben a kerület. Ez alól azonban kivételt képeznek azok az útszakaszok, amelyeket a rendelet melléklete a fővárosi önkormányzat kezelésébe sorol, függetlenül azok tulajdonosától. A rendelet szerint szintén fővárosi kezelésbe kerülnek a mellékletben fel nem sorolt, de fővárosi tulajdonú útszakaszok. Mindezeken kívül, a rendelet lehetőséget nyújt, kétoldalú megállapodások alapján, a kezelői feladatok másik szervezetnek való átadására. A jogi 


\section{Közúti közlekedés}

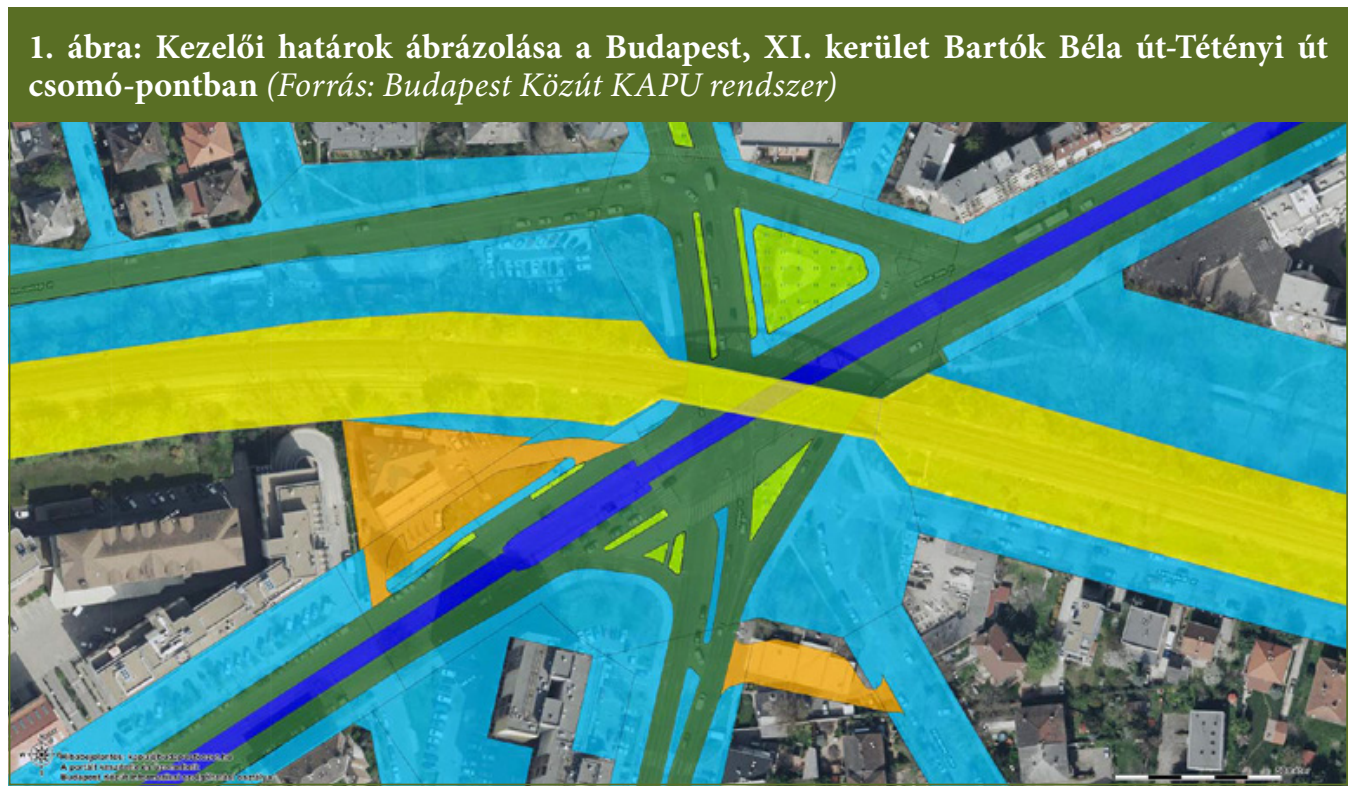

környezet az útpályák tekintetében zárt rendszert alkot, azonban - bonyolultságából fakadóan - a napi működésben számos félreértést okoz(hat).

Budapesten a helyzetet még tovább bonyolítja, hogy a fövárosi önkormányzat a közútkezelői feladatokat több szakcége között felosztotta. A BKK Zrt. mint stratégiai közútkezelö, a Budapest Közút Zrt. mint operatív közútkezelö, a BKV Zrt., mint a városi vasutak kezelője, az FKF Zrt., mint a téli síkosság-mentesítésért és téli-nyári úttisztításért felelős, az FCSM Zrt., mint a felszíni csapadékvíz elvezetésért felelős, a Főkert Zrt. pedig mint a KRESZ gallyazásért és egyéb kertészeti munkákért felelös szervezet jut szerephez a közútkezelésben. Ha hozzáveszszük, hogy magántársaságok (benzinkutak, bevásárlóközpontok tulajdonosai) is rendelkeznek közforgalom számára megnyitott magánutakkal, elöfordulhat, hogy egy csomópont területén, közútkezelői feladatokban akár 7-8 társaság is érintett (1. ábra).

A felvázolt igazgatási szerkezetben nem csupán a felelősségek meghatározása okoz(hat) nehézséget, de a rendszerben az erőforrások is szétaprózódnak. Komoly adminisztratív terhet jelent egy-egy nagyobb beruházás egyezte- tése, a különböző érdekek összehangolása. Sok esetben, ez beruházások ésszerűtlen elhúzódásával vagy - szélső esetben - akár elmaradásával is jár. A fövárosi helyi közutak kezelésének szakmai szabályairól, továbbá az útépítések, a közterületeket érintő közmü-, vasút- és egyéb építések és az útburkolatbontások szabályozásáról szóló Fővárosi Közgyülési Rendelet [15] a közútkezelöi érdek egységes érvényesítését célozza. A rendelet a Fővárosi Önkormányzat kezelésében lévő helyi közutakra vonatkozik, míg a kerületi önkormányzatok egy részének nincsen közútkezelői rendelete, így a helyreállítás módjára vonatkozó műszaki előírások sem egységesek.

\section{BURKOLAT-ÁLLAPOTPARAMÉ- TEREK JELENTÓSÉGE TELEPÜ- LÉSI UTAKON}

Közismert, hogy az útállapot olyan komplex jelenség, amit csak különböző állapotparaméterek pillanatnyi értékének kombinációjával lehet reálisan jellemezni. Az egyes állapotparaméterek jelentősége azonban attól is függ, hogy az országos közúthálózatról (annak is elsősorban külsőségi szakaszairól) vagy pedig települések (így, egyebek mellett, a fóváros) közúthálózatáról van szó. Ezért a már többször említett, 2018-as kutatási jelentés [11] 


\section{Közúti közlekedés}

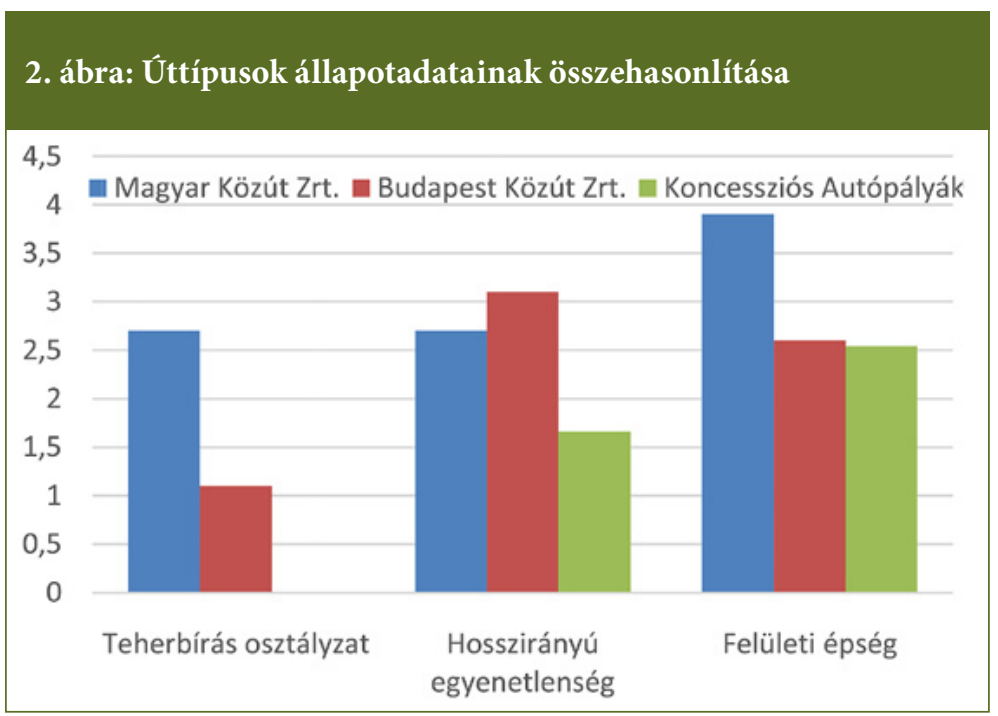

készítésekor, a városi közúthálózat minősítésekor szóba jövő állapotjellemző paraméterek jelentőségét átgondolták, különös tekintettel az egyes adatok mérési bizonytalanságaira. Foglalkoztak a burkolatállapot-értékelés és az állapotjavító beavatkozási javaslatok esetleges forgalomfüggésének kialakításával. Majd pedig a különbözö beavatkozási határokra, valamint a beavatkozások állapotértékekre gyakorolt hatására is kitértek.

Jelenleg a Budapest Közút Zrt. az egyes útszakaszok állapotát felületi épség (a kerületi létesítményfelelősök által vizuálisan), a pályaszerkezet-teherbírás (Lacroix-deflektográffal), valamint a hossz- és a keresztirányú felületi egyenetlenség, IRI és keréknyomvályú-mélység (KARESZ lézer pontfelhőjéből készített, terepmodellen alapuló, számított adatok) mérésével jellemez. A városi utak jellegzetes leromlási (tönkremeneteli) formáinak összehasonlító elemzése arra a kutatói megállapításra jutott, hogy a repedezés és a kátyúképződés típusú romlások gyakoribbak és nagyobb jelentőségűek, mint a deformáció jellegüek. (Természetesen, ez utóbbiak is válhatnak, adott esetben, mértékadókká).

Az összehasonlító vizsgálatra szóba jövő burkolatállapot-paraméterek: felületi épség (felületépség), hosszirányú felületi egyenetlenség (IRI), keresztirányú felületi egyenetlenség (keréknyomvályú mélység), pályaszerkezet-teherbírás, csúszásellenállás. (Az országos közutak állapotjellemzésében, különösen külföldön, egyre gyakrabban alkalmazott pálya-gördülőzaj mérése, a pálya fényviszszaverő képességének meghatározása, illetve a burkolatfelületen jelentkező vízköd-, illetve - másszóval vízfüggöny-képződés jellemzése a városi utak esetében elhanyagolható jelentőségü). Az állapotparaméterek jelentőségét (súlyát) a „városi szempontok" nagymértékben befolyásolják.

A folyamatos (nem pontszerű) állapotjellemzési technológiák számos előnnyel rendelkeznek. Emellett azonban döntést igényelnek a tekintetben, hogy az irányonként egynél több forgalmi sávval rendelkező utakon a mérés mely sávokra vonatkozzék, nem elfelejtkezve az autóbuszöblök különleges állapotminősítési problémájáról sem. A városi környezetben viszont feltétlen elönyt jelentenek a folyamatos állapotjellemzési technológiák, mivel a csomópontok rendkívüli sürüsége és a közmüveknek sok helyen előforduló javítási helyei, a szerelvény- és a vezetékcserékkel együtt, sok helyen inhomogén pályaszerkezetet hoznak létre.

A városi, közúti közlekedés különlegességeinek, illetve jellegzetes tönkremeneteli formáinak figyelembevételével, a burkolatállapotot jellemző paraméterek jelentősége a következőképpen ítélhető meg:

- felületi épség (kiemelt jelentőségü, a burkolatminőség úthasználók által történő megítélését elsősorban ez az állapotparaméter befolyásolja),

- pályaszerkezet-teherbírás (kiemelt jelentőségű, elsősorban az útkezelő vagyongazdálkodási kötelezettsége következtében, valamint amiatt, hogy más, 


\section{Közúti közlekedés}

esetenként a közeljövőben várható burkolat-meghibásodási forma kiváltója, illetve előjelzője lehet),

- hosszirányú felületi egyenetlenség (közepes jelentőségű, fontossága a 60-70 $\mathrm{km} / \mathrm{h}$-s megengedett sebességü szakaszokon és a nagy forgalmi terhelésü csomópontok elötti felgyürődések esetében növekszik, amit az osztályzatok értékhatárainál érvényre lehet juttatni),

- keresztirányú felületi egyenetlenség (közepes jelentőségü, utazáskényelmi problémákat okoz, illetve, mély nyomvályúk esetében, a 60-70 km/h-s megengedett sebességű, közel vízszintes szakaszokon, a vízen csúszás - az aquaplaning - veszélyével kell számolni; ezt a tényt pedig az osztályzatok értékhatárainál itt is érvényre lehet juttatni),

- a pálya textúrája, csúszásellenállása (korlátozott jelentőségü, legfeljebb - különösen síkos burkolatfelületnél - esetenként a jármüvek gyors megállását igénylö, forgalmi csomópontok előtti szakaszokon lehet érdemleges szerepe).

A pálya csúszásellenállásának a jellemzésére a KARESZ pontfelhő [3] nem alkalmas. A hossz- és a keresztirányú felületi egyenetlenségröl, ugyanakkor, képes hasznos információkat szolgáltatni.

A jelenleg jellemzett állapotparaméterek közül, a legtöbb bizonytalanság, annak vizuális-szubjektív jellegéből következően, a felületi épség minősítését terheli. Ezért felmerülhet a jelenleg követett technikának a KARESZfényképeken alapuló értékeléssel való felváltása. A váltás azonban csupán az újonnan javasolt állapotjellemzési módszer alkalmazásában érdekelt szakemberek megfelelö felkészítése után képzelhető el. Addig a jelenleg követett eljárás, a létesítményfelelősök öt fokozatú értékelése folytatódhat. Az eljárás bizonytalanságainak csökkentésére összehangolt oktatás javasolható. (Ebben a tekintetben, a Magyar Közút Nonprofit Zrt.-nek a Roadmaster burkolathiba-vizsgáló berendezéssel kapcsolatos oktatásának a tapasztalatai hasznos információkkal szolgálhatnak.)
A hálózati szintű állapotadatok feldolgozása után, választott beavatkozási projektek tervezett, létesítményi szintü állapotvizsgálata, célszerüen, csak a felületépségre terjedjen ki. Ennek pontosabb, részletekbe menő ismerete a leglényegesebb, mivel ritka eset, hogy városi úthálózaton másik állapotparaméter válik mértékadóvá (az állapotjavító beavatkozást, a többieket megelőzően, szükségessé tevő) paraméterré. Megjegyzésre érdemes, egyébként, az is, hogy a teljes pályaszerkezeti rétegeket érintő, megfelelő minőségben végrehajtott felújítás gyakorlatilag minden egyes állapotparaméterre kedvező hatást gyakorol.

Általánosságban elmondható, hogy az egy forgalmi irányú, több sávos utak esetében, minden forgalmi sáv állapotadatainak az összes paraméter esetében való felvételére nincsen szükség. Elegendő a (leg)külső sáv minősítése, mivel a pályaszerkezetet igazán igénybe vevő nehéz forgalom, így a menetrendszerü autóbuszok és trolibuszok is, föleg itt közlekednek. Elsősorban a Lacroix-mérőkocsival (deflektográffal) végzett pályaszerkezet-teherbírás az az állapotparaméter, amelynek esetében az előbbi megállapítás gyakorlati következményekkel járhat. (A KARESZ pontfelhő és a létesítményfelelős vizuális állapotfelvételének azonban nem kell csak egyes forgalmi sávokra korlátozódnia).

Az autóbuszöblöt önálló „homogén szakasznak" célszerü tekinteni, külön gyüjtött állapotadatokkal. A pályaszerkezet teherbírásának mérése, föleg betonburkolatú öblök esetében, elhagyható. Egy-egy autóbuszöböl, szükség esetében, a többivel versenyző, beavatkozási projekt lehet.

\section{JELENLEGI PÁLYASZERKEZET- MÉRETEZÉSI ELJÁRÁSOK VÁ- ROSI KORLÁTAI}

Ahogy az utakra ható terhelés, úgy az utakkal kapcsolatos elvárások is különbözőek a külterületi és a városi szakaszokon. A jelenlegi pályaszerkezet-méretezési eljárásokat [16] is alapvetően a külsőségi szakaszok méretezésére fejlesztették ki. Az eljárások részben a városi 
3. ábra: Erősítést igénylő pályaszerkezet-behajlások, forgalmi tervezési osztályonként

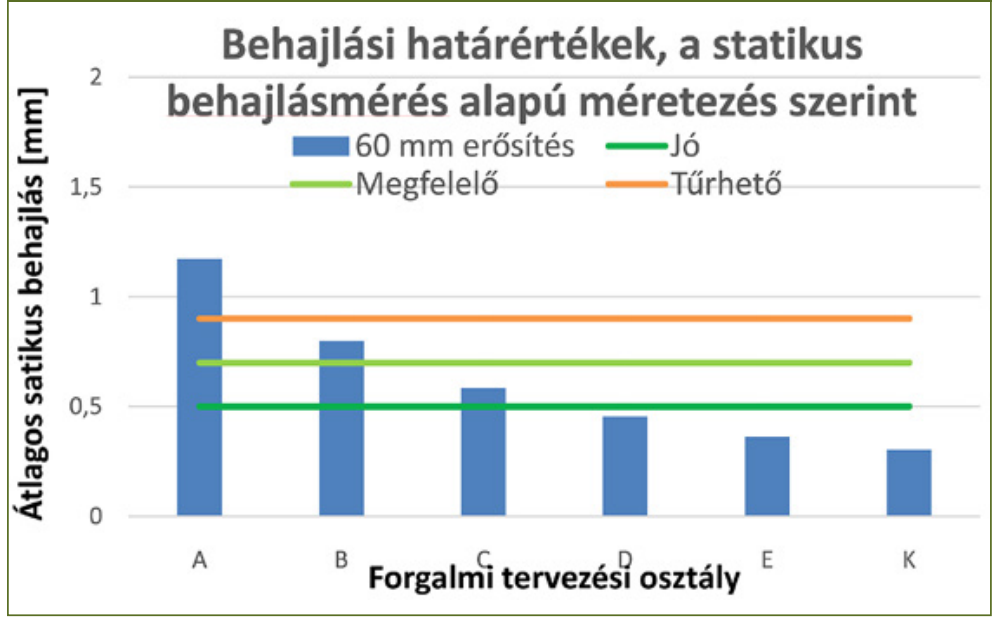

tesz szükségessé. Pedig a $0,6 \mathrm{~mm}$-es pályabehajlás megfelelö teherbírású - szinte újszerü szakaszokat jellemzi! Ezeknek az utaknak az általános jellemzői: jó teherbírás, betömörödött makadám vagy soványbeton burkolatalapok, „elöregedett” útpálya, pályaszintemelést korlátozó körülmények. A pályaszerkezet jellemző felépítése: 70$80 \mathrm{~mm}$-nyi összes vastagságú aszfaltrétegek alatt 200 mm-nyi soványbeton alap. pályaszerkezetek méretezésére is megfelelöek, azonban alkalmazásakor sokszor komoly nehézségek merülnek fel. Budapest főúthálózatáról, az országos közúthálózathoz viszonyítva, a következők állapíthatók meg:

- sokkal jobb az útpályaszerkezetek teherbírása,

- a városi szakaszokra jellemző módon, a pályaszint emelése korlátokba ütközik.

Az említett méretezési eljárás [16] azonban még a viszonylag jó teherbírású pályaszerkezetek esetében is a szerkezeti vastagság növelését írja elö. Ez azonban, az ismert magassági korlátozások miatt, rendszerint csak teljes pályaszerkezetcserével és a földmü mélyítésével lehetséges.

A 3. ábrán látható, hogy különböző forgalmi tervezési osztályok esetében, a statikus behajlás alapú méretezési eljárás milyen átlagos, statikus, behajlási értéknél javasol $60 \mathrm{~mm}$-es vastagságú pályaszerkezet-erősítést. A pályaszint $60 \mathrm{~mm}$-es emelése, kiemelt szegélyekkel épült városi környezetben jellemzően már nem megoldható, ezért ilyenkor a pályaszerkezet teljes cseréje szükségessé válik.

A fövárosi főutakat jellemző, $\mathrm{C}-\mathrm{K}$ forgalmi tervezési osztályokban, 0,3-0,6 mm-es átlagos pályabehajlás már $60 \mathrm{~mm}$-es vastagságú erösítést
A méretezési eljárás [16] alkalmazásával az adódik, hogy a pályaszerkezeteket erősíteni kellene. Mivel azonban nem lehet a pályaszintet emelni, el kell a jó minőségű burkolatalapokat bontani. Az összehasonlító méretezés nem veszi figyelembe, hogy a makadám burkolatalapok az elmúlt évtizedek alatt „beálltak”, kiváló szilárdságúvá váltak. Ezek az eljárások nem számolnak azzal, hogy az összetöredezett, rossz minőségű pályaszerkezeti rétegek ugyanolyan vastagságú, hasonló összetételü, de új (kiváló állapotú) réteggel történő cseréje a szóban forgó pályaszerkezetet érdemben erősíti. A 4. ábra azt mutatja be, hogy a föváros föútjainak jelenleg hol lenne szüksége a méretezési eljárás alapján $60 \mathrm{~mm}$-nél nagyobb megerősítésre (vagyis pályaszerkezet-cserére), illetve hol van szükség ténylegesen teljes pályaszerkezet-cserére. Az ábrán látható, hogy a magassági korlátozások miatti pályaszerkezet csere komoly többletforrást igényel. Érdemes lehet tehát a jelenlegi méretezési eljárások helyett hosszú távon is költséghatékonyabb módszereket találni.

\section{ETALONSZAKASZOK KIVÁLASZ- TÁSA}

Jogos kérdésként merül fel, hogy az útfenntartás tervezéséhez és a felmerülő költségek optimalizálásához alapul vett leromlási fo- 


\section{Közúti közlekedés}

\section{4. ábra: A fơváros fơútszakaszai, teljes pályaszerkezetcserével}

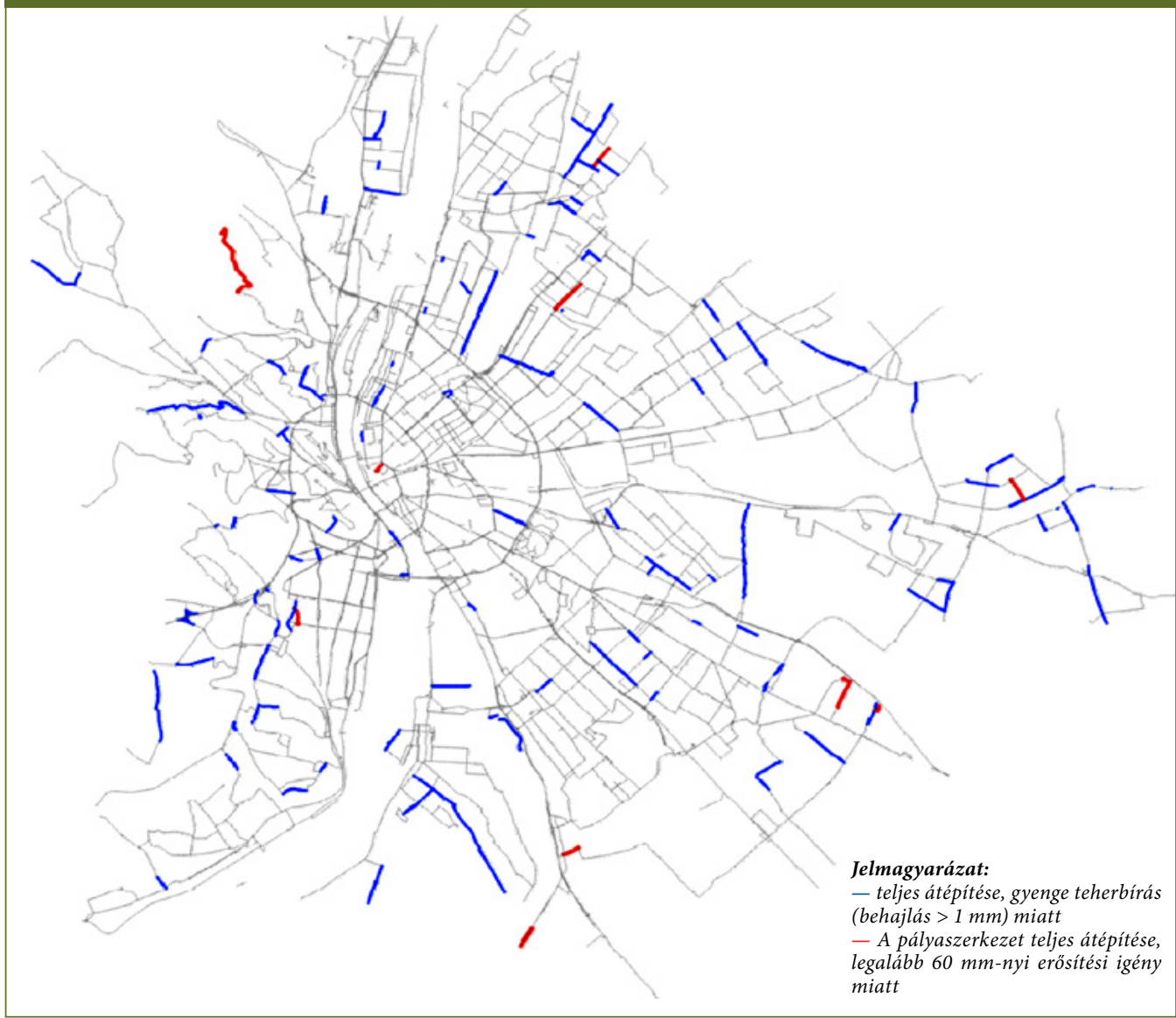

lyamatok előrebecslésének lehető legnagyobb mértékű pontossága miként biztosítható. A rendszerszemléletű útgazdálkodási döntések elengedhetetlen elöfeltétele, hogy a különböző forgalomnagyságú, pályaszerkezetü, illetve földmü szilárdsággal rendelkező stb. útszakaszok várható élettartamáról elfogadható megbízhatóságú ismeretekkel rendelkezzenek. A sok ható tényező és azok nehezen modellálható, szinergikus egymásra hatása a kérdéskört meglehetősen bonyolulttá, elméleti megközelítésekkel egyenesen megoldhatatlanná teszi. Ezen a területen a laboratóriumi vizsgálatok sem segítik az öszszetevők egyértelmű empirikus úton történő alátámasztását. Még a mesterséges forgalommal terhelt próbapályák variációs lehetőségei is - akár a pályaszerkezet-felépítés, akár az időjárási viszonyok modellálása szempontjából - a komplex feladat megoldásához túlságosan korlátozottak. Egyetlen lehetöségként, marad az úthálózatból gondosan - tudományos alapossággal - megtervezett szempontok alapján kiválasztott, megfelelö hosszúságú etalonszakaszok állapotváltozásának hosszabb időn keresztül történő megfigyelése [18-19]. Az etalonszakaszok kiválasztási szempontjainak rögzítése, majd azok következetes végrehajtása meglehetősen felelősségteljes feladat. A következőkben ezek közül a legfontosabb szempontokról teszünk említést, hangsúlyozva a városi utakon folyó közlekedésnek a külsőségi szakaszokétól eltérő jellemzőit. 
Fontos szempont az egész úthálózatra jellemző etalonszakaszok számának meghatározása. Itt egyrészt annak az eldöntése okozhat nehézséget, hogy hány forgalmi, pályaszerkezeti stb. kategóriát jelöljenek ki, másrészt pedig az egy útszakasz-csoportot jellemző etalonszakaszok száma (egyetlen etalonszakasz azért nem képviselhet egy megfigyelési kategóriát, mivel a szakasz esetleges, átlagostól eltérő viselkedését nem vagy nem könnyen lehet - összehasonlítási alap hiányában - felismerni).

A következő elvi nehézség a rendszeresen jellemezhető állapotparaméterek kiválasztásában rejlik. Itt azt az alapelvet célszerü érvényesíteni, hogy minden olyan paramétert (pályaszerkezet-teherbírás, hosszirányú felületi egyenetlenség, keréknyomvályú-mélység, érdesség, csúszásellenállás stb.) be kell az értékelési körbe venni, amely egyrészt a szóban forgó úthálózaton mértékadó - a többiek előtt beavatkozást igénylő - állapotszintre szokott jutni, más részről pedig, amelynek jellemzéséhez az útkezelő megfelelő, reprodukálható eredményeket biztosító, mérési technikával rendelkezik. Természetesen, a „vágyaknak” a pénzügyi lehetőség itt is határt szab.

Lényeges vizsgálandó kérdés az állapotjellemzések időbeni sürüsége, ahol - az egyes állapotparaméterek eltérő leromlási sebessége miatt - akár különböző visszatérési gyakoriság is szóba jöhet. (Így, például, a pályaszerkezet teherbírása, - általános esetben - ritkább nyomon követést igényel, mint a felületi hibák vagy a makro érdesség változása). Ennek az eljárásnak ugyan szervezési nehézségei lehetnek, és azt is figyelembe kell venni, hogy az élettartam vége felé az állapotparaméterek egyébként lassú leromlása is felgyorsulhat.

Egy-egy útszakasz-csoportot több (célszerüen három) etalonszakasznak kell jellemezni az esetleges tervezési, építési, illetve fenntartási anomáliák hatásának, lehetőség szerinti, csökkentése érdekében. Feltétlenül el kellene ugyanis kerülni, hogy az etalonszakasz „egyedi hibái” torzítsák az egész, akár 100 km-nyi összes hosszúságú hálózatrész állapotának elörebecslését - az etalonszakaszok hosszú távú állapotának nyomon követésekor a fö célt. Mindezek tekintetében a következő nyolc útszakasz-csoport (és ebből következőleg $3 \times 8=24$ etalonszakasz) kijelölését javasoljuk:

- kötött altalaj (Buda) + kötőanyag nélküli alapréteg + több autóbusz-trolibusz járat;

- kötött altalaj (Buda) + hidraulikus kötöanyagú alapréteg + több autóbusz-trolibusz járat;

- kötött altalaj (Buda) + kötőanyag nélküli alapréteg + nincs több autóbusz-trolibusz járat;

- kötött altalaj (Buda) + hidraulikus kötőanyagú alapréteg + nincs több autóbusztrolibusz járat;

- szemcsés altalaj (Pest) + kötőanyag nélküli alapréteg + több autóbusz-trolibusz járat;

- szemcsés altalaj (Pest) + hidraulikus kötőanyagú alapréteg + több autóbusz-trolibusz járat;

- szemcsés altalaj (Pest) + kötőanyag nélküli alapréteg + nincs több autóbusz-trolibusz járat;

- szemcsés altalaj (Pest) + hidraulikus kötőanyagú alapréteg + nincs több autóbusz-trolibusz járat.

Az etalonszakasz úthálózatból történő kiválasztására vonatkozó alapelvek a következők:

- a kiválasztott etalonszakaszok 200-400 fm-es hosszúságú, egyenesben levő, két forgalmi sávos útszakaszok legyenek, amelyeknek kiviteli (és esetleges felújítási) tervei rendelkezésre állnak; a pályaszerkezet-felépítése, földmü-jellemzői, az eddigi állapotjavító beavatkozásainak időpontja és technológiája, az építése óta évente végzett kátyújavítások mennyisége, megépítése óta az évenkénti - fóleg nehézforgalom nagysága, ezen belül az esetleges autóbusz- és trolibuszforgalom mértéke, az eddigi vizuális és mérőberendezéssel végzett állapotvizsgálatok időpontja és eredményei ismeretesek;

- célszerű előtérbe helyezni a viszonylag új építésű szakaszokat, mivel az állapotadatok gyüjtését minél "fiatalabb korban” célszerü elkezdeni;

- az évente gyüjtendő és idősorba állítandó (leromlási görbék) állapotparaméterek a következők legyenek: 


\section{Közúti közlekedés}

o felületi épség (két független értékelő személlyel és KARESZ fényképekkel való ellenőrzéssel, 5 fokozatú állapotosztályzat),

o pályaszerkezet-teherbírás (Lacroixmérőkocsival, a szakasz mértékadó behajlása, mm-ben),

o hosszirányú felületi egyenetlenség (a KARESZ pontfelhőből számított IRI érték, a külső „keréknyomban”, a két forgalmi sáv közül a kedvezötlenebb érték, $\mathrm{m} / \mathrm{km}$ vagy $\mathrm{mm} / \mathrm{m}$ ),

o keresztirányú felületi egyenetlenség (a KARESZ pontfelhőből számított átlagos keréknyomvályú-mélység, a külső „keréknyomban”, a két forgalmi sáv közül a kedvezőtlenebb érték, mm);

o időjárási adatsorokat (csapadék, hőmérséklet) is szükséges gyüjteni az etalonszakaszokhoz kapcsolódóan minél közelebbi helyekről. Ezek az adatok elsősorban a váratlan állapotváltozások okainak kutatásakor juthatnak szerephez, de szükségesek a teherbírás mérésekor alkalmazandó hömérsékleti korrekcióhoz is.

\section{A HOMOGÉN SZAKASZOK MEGHATÁROZÁSÁNAK ELVE}

A Budapest Közút Zrt. számára kidolgozás alatt levő útburkolat-gazdálkodási rendszer [11] fontos elemét képezi, a rendelkezésre álló adatok alapján, a homogén szakaszok meghatározásának legmegfelelőbb módszerére vonatkozó javaslat. (Hiszen ebben a rendszerben egy-egy homogén szakasz lehetséges beavatkozási projektnek is tekinthető).

A KTI Nonprofit Kft. által 2010-ben készített kutatási jelentés [1] homogén szakaszok helyett, az egyes szomszédos föút-csomópontok között, még a burkolatállapot felvétele előtt, értékelési részszakaszok kijelölését javasolja. (Indokul azt hozza fel, hogy az egyes részszakaszok így közel hasonló hosszúságúak lesznek, valamint, hogy ezzel a csomópontoknál a forgalomban, a pályaszerkezet felépítésében, a forgalomszabályozásban stb. esetlegesen bekövetkező változások követhetővé válnak).
Ehhez kapcsolódóan a következőket javasolták még:

- 300 m-esnél kisebb csomópont-távolság esetén részszakasz nem képezhető,

- ha a két szomszédos csomópont távolsága 301 és $600 \mathrm{~m}$ közötti, akkor a szakasz középpontjában részszakasz-végpontot kell felvenni,

- a szomszédos csomópontok $600 \mathrm{~m}$-t meghaladó távolsága esetében, 300 m-enként részszakasz-végpontot kell kijelölni, az utolsó pont azonban a maradék 301-600 m-es hosszúságú rész középpontjába kerül.

A homogén szakaszok képzése elött, a rendelkezésre álló állapotadatok állományát a hibás (pl. 6-os állapotosztályzat) vagy pedig az irreálisan kiugró (outlier) értékektől „tisztítani” kell. Ezeket a két szomszéd érték átlagával célszerü helyettesíteni.

A KTI 2018-as kutatási munkája [10] azt a megoldást ítéli logikusnak, hogy a homogén szakaszokat, a vizsgálati szemponttól függően, a következő, eltérő alapelveket követve jelöljék ki:

- felületi épség: két szomszédos fơút (a Budapest Közút Zrt. által kezelt út) keresztezése közötti útszakasz; kivéve, ha annak egyes részei határozottan (szembe szökően) különböző állapotúak és/vagy burkolattípusúak;

- pályaszerkezet-teherbírás: az MSZ 25094:89 szabvány [15] homogén szakasz képzési elöírásai szerint (amennyiben mindkét forgalmi irányban mérték a teherbírást, a két sáv behajlási adatait egyetlen adathalmaznak kell tekinteni);

- hosszirányú felületi egyenetlenség: IRI osztályzatonként (az 1-3-as, a 4-es és az 5-ös osztályzat váltásakor - homogén szakasz váltása; nyilvánvalóan, a jó - az 1-es, a 2-s és a 3-as - osztályzatok váltása a homogén szakaszok képzésekor figyelmen kívül hagyható, azokat egyformán 1-es osztályzatúnak tekintve);

- keresztirányú felületi egyenetlenség: keréknyomvályú-mélység osztályzatonként (az 1-3-as, a 4-es és az 5-ös osztályzat váltásakor - homogén szakasz váltása; nyilvánvalóan, a jó - az 1-es, a 2-s és 
a 3-as - osztályzatok váltása a homogén szakaszok képzésekor figyelmen kívül hagyható, illetve azokat egységesen 1-es osztályzatúnak kell tekinteni);

- forgalmi terhelés: két szomszédos főút (a Budapest Közút Zrt. által kezelt út) keresztezése közötti útszakasz között, az ÁNF átlagát véve alapul;

- burkolattípus: szemmel látható burkolattípus-váltások között. (Ameddig a pályaszerkezetek felépítése, hitelt érdemlő módon, az érintett hálózatról nem ismert, csak a vizuálisan is megítélhető burkolat vehető alapul). Ha vannak a pályaszerkezet felépítésére vonatkozó információk is, akkor a homogén szakasz végének a teljes pályaszerkezetben bekövetkező lényeges változás (pl. kötőanyag nélküli burkolatalapról hidraulikus kötőanyagúra való váltás) tekinthető.

Először az állapot, a forgalmi jellemzők és a pályaszerkezet típusa szerinti „kombinált” homogén szakaszokat kell meghatározni, majd azt vizsgálják, hogy azoknak indokolt-e a szomszédos „kombinált” homogén szakasszal való összevonása, amikor „lehetséges beavatkozási projektet” alakítanak ki.

Ezután a szóba jövő (javasolt) beavatkozási technológia kiválasztása következik, az azzal kapcsolatos, legkisebb, beavatkozási hosszúság függvényében is. (Erre a legkisebb felújítási beavatkozási hosszúságra a következők javasolhatók: pályaszerkezet átépítése $500 \mathrm{~m}$, a többi felújítási technológia esetében $300 \mathrm{~m}$ ). Célszerü megoldás, hogy a „lehetséges beavatkozási projektet" fóút-keresztezés határolja, valamint, hogy az a szakasznak csupán egyik pályájára, csak kivételes esetekben korlátozódjék.

Annak a feltételezésével, hogy a homogén szakaszok képzése a különböző, mért állapotparaméterek, a forgalomnagyság és a burkolattípus szerint, egymástól eltérő elvek (szabályok) szerint történik, elengedhetetlen azok valamilyen, előzetesen meghatározott eljárással történő kombinálása. Az általános esetben, különböző hosszúságú homogén szakaszok kombinálásakor a következő elvek, illetve szabályok követését javasoljuk:
- első lépésben, a teherbírás szempontjából lokálisan (legfeljebb 300 m-es hoszszúságban) - környezetéhez képest is - nagyon gyenge teherbírású pályarészeken, részletesebb vizsgálatot követően, megtervezett technológiával, nagyfelületi javításra („szőnyegezésre”) kerüljön sor;

- az összevont homogén szakasz legalább a felületi épség osztályzat által meghatározott, általában két szomszédos fótu-csomópontot összekötő, homogén szakasz hosszúságú legyen;

- ezt a homogén szakaszt akkor és abban az irányban kell meghosszabbítani, ha valamelyik végéhez 5 -ös, illetve 4 -es felületi épség és/vagy 5-ös, illetve 4-es pályaszerkezet-teherbírás osztályzatú és/vagy 5-ös osztályzatú hossz- vagy keresztirányú felületi egyenetlenségi homogén szakasz csatlakozik.

Az állapotjavító beavatkozás határa (azaz a felújítás indoka) a következő állapotkombinációk valamelyike lehet:

- az 5-ös felületi épség osztályzat (önmagában),

- a 4-es vagy az 5-ös teherbírás osztályzat (önmagában),

- a 3-as teherbírás osztályzat + a 4-es felületi épség osztályzat (egy szakaszon, egy időben),

- az 5-ös hosszirányú felületi egyenetlenség osztályzat + a 3-as teherbírás osztályzat és/vagy 4-es felületi épség osztályzat (egy szakaszon, egy időben),

- az 5-ös keresztirányú felületi egyenetlenség osztályzat + a 3-as teherbírás osztályzat és/vagy 4-es felületi épség osztályzat (csak a személygépkocsik számára 50 $\mathrm{km} / \mathrm{h}$ feletti, megengedett sebességü útszakaszokon, egy időben),

- az 5-ös hosszirányú felületi egyenetlenség osztályzathoz tartozó legkisebb IRI értékét legalább 20\%-kal meghaladó egyenetlenség (5+ osztályzat) (önmagában)

- az 5-ös keresztirányú felületi egyenetlenség osztályzathoz tartozó legkisebb keréknyomvályú-mélység értékét legalább 20\%-kal meghaladó egyenetlenség 


\section{Közúti közlekedés}

(5+ osztályzat), az $50 \mathrm{~km} / \mathrm{h}$ feletti, megengedett személygépkocsi-sebességü útszakaszokon (önmagában).

Ez az osztályzatkombináció-sor abban az esetben célszerüen módosítandó, ha egyes változatok a gyakorlatban nem vagy alig fordulnak elö. Ilyen esetben szóba jöhet az osztályközök módosításának a lehetősége is.

Az útszakaszon lebonyolódó, nem kötött pályás közösségi közlekedés, illetve annak sürüsége, valamint a pályaszerkezet-, illetve a burkolattípus a választandó, beavatkozási technológiát befolyásolja. Az előbbiekben felsorolt beavatkozási indokok valamelyikét „kielégíto"” (az állapotinformációk célszerü leválogatásával kijelölhető) homogén szakaszokat - azaz más szóval „szükséges beavatkozási projekt"-eket - meg kell vizsgálni, hogy azok hosszúsága a 300 m-t meghaladja-e:

- amennyiben igen, akkor ezt tekintjük „kombinált homogén szakasznak”, és ehhez rendeljük hozzá az „optimális beavatkozás-típust”, figyelemmel a technológia legkisebb beavatkozási hosszára (átépítés igénye esetében, a $300 \mathrm{~m}$-es helyett 500 m-es legkisebb szakaszhossz veendő tekintetbe);

- amennyiben hosszúsága a 300 m-t (500 $\mathrm{m}-\mathrm{t}$ ) nem éri el, akkor azt a két szomszédos homogén szakasz közül, a rosszabbik állapotúval javasolt összevonni.

Az autóbuszöblöket önálló homogén szakasznak célszerü tekinteni, és azokon csak a felületi épség osztályzatot meghatározni. Ha a felületi osztályzat 5-ös, akkor a szóban forgó autóbuszöböl a „szükséges beavatkozási projekt"-ek sorába kerül.

\section{8. ÖSSZEFOGLALÓ MEGÁLLAPÍTÁ- SOK}

A Budapest Közút Zrt. számára a közelmúltban összeállított útburkolat-gazdálkodási rendszer [11], a 8 évvel korábban készült első változat [1] továbbfejlesztéseként alapvetően hálózati jellegü; ugyanakkor a részletesebb, létesítményi (projekt) szintü PMS elveit is rögzítették. $\mathrm{Az}$ újabb burkolatgazdálkodási rendszer az előbbinél egyértelmüen alkalmasabb arra, hogy a Budapest Közút Zrt. rövid és középtávú burkolatfelúítási stratégiáit, a számos befolyásoló tényező kölcsönhatásának figyelembevételével, megbízhatóbban kialakíthatóvá tegye.

Ugyanakkor azonban a közeljövő továbbfejlesztési irányai is nyilvánvalókká válnak, elsősorban a következő irányokban: a különböző burkolatállapot-paraméterek mérésére, illetve jellemzésére szolgáló eljárások továbbfejlesztése, pontosítása; etalonszakaszok kijelölése és rendszeres állapotvizsgálatának elkezdése; a hálózat egyes útszakaszairól pályaszerkezet-felépítési információk gyüjtése és a rendelkezésre álló adatok megbízhatóságának növelése; a burkolatok alatti közművek mennyiségi és minőségi információinak öszszegyüjtése és a PMS-ben való hasznosítása; a hálózaton folyó pontszerü beavatkozások független minőségellenőrzési rendszerének kialakítása.

\section{FELHASZNÁLT IRODALOM}

[1] Dr. Gáspár László (KTI Közlekedéstudományi Intézet Nonprofit Kft.): PMS I. mérnöki változatának validálása és továbbfejlesztése. 2010, 198 p.

[2] Dr. Bakó András - dr. Ambrusné Somogyi Kornélia (Universitas Alapítvány Győr Nonprofit Kft.): PMS Matematikai Modelljének elkészítése és továbbfejlesztésének előkészítése. 2010, 63 p.

[3] BKK Közút Zrt.: Projektbeszámoló KTI PMS modelljének adaptálása a BKK Közút rendszerébe, és a továbbfejlesztési irányok meghatározása c. projektről. 2015, 68 p.

[4] Soós Zoltán - Igazvölgyi Zsuzsanna (BME): Vélemény a „Projektbeszámoló KTI PMS modelljének adaptálása a BKK Közút rendszerébe, és a továbbfejlesztési irányok meghatározása c. projektről”, 2015, 4 p.

[5] Dr. Ambrus Kálmán (Intelligens utak Mérnökiroda Kft.): Budapest Közút Zrt. PMS rendszer továbbfejlesztése, tanulmány, 2015, 66 p.

[6] Dr. Gáspár László (KTI Közlekedéstudományi Intézet Nonprofit Kft.): A forgalom áramlásának vizsgálata. 2012, 134 p. 
[7] Budapest Közút Zrt.: Beszámoló a 2015. évi Futtatás eredményeiröl. 2016, 45 p.

[8] Budapest Közút Zrt.: Beszámoló a 2016. évi Futtatás eredményeiről. 2017, 39 p.

[9] Budapest Közút Zrt.: Beszámoló a 2018. évi Futtatás eredményeiröl. 2018, 29 p.

[10] Dr. Gáspár László (témafelelős): Budapest Közút Zrt. Burkolatgazdálkodási rendszerének felülvizsgálata és továbbfejlesztése. 2018, 81 p.

[11] Dr. Gáspár László (témafelelős): Útgazdálkodási célú etalonszakasz megfigyelés kiértékelése. A KTI Nonprofit Kft. VB2018/0027529/00 számú témájának zárójelentése. Budapest, 2018. 134 p.

[12] László Gáspár - Márton Karoliny - Csaba Tóth: Predicting subgrade strength using FWD and meteorological time series data. Proceedings of 10th International Conference on the Bearing Capacity of Roads, Railways and Airfields, Athens, Greece, 2017, pp. 2117-2125. DOI: http://doi.org/dpbs

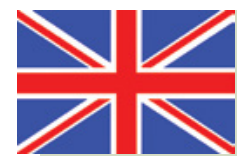

\section{The characteristics of urban road management}

The recently developed pavement management system (PMS) for Budapest Közút Zrt. (the company responsible for the management of the roads on Budapest) is, as an improvement of the first version created 8 years ago, essentially network-based; however, the principles of a more detailed, facility (project)-level PMS have also been established. The new pavement management system is clearly more suitable than the previous one to make the short-term and medium-term pavement renovation strategies of Budapest Közút Zrt. implementable in a more reliable way, taking into account the interaction of several influencing factors.
[13] 432/2012. (XII. 29.) Korm. rendelet a Fővárosi Önkormányzat kezelésében lévő foútvonalak, közutak és közterületek kijelöléséröl

[14] 2011. évi CLXXXIX. törvény Magyarország helyi önkormányzatairól

[15] 34/2008. (VII. 15.) Főv. Kgy. rendelet a fövárosi helyi közutak kezelésének és üzemeltetésének szakmai szabályairól, továbbá az útépítések, a közterületet érintő közmü-, vasút- és egyéb építések és az útburkolatbontások szabályozásáról

[16] e-UT 06.03.13. [ÚT 2-1.202:2005] „Aszfaltburkolatú útpályaszerkezetek méretezése és megerősítése

[17] Marianna Csicsely-Tarpay - András Bakó László Gáspár - László Marton: Hungarian Pavement Management System for the Road Network of a City. Second International Conference of Road \& Airfield Pavement Technology, Singapore, 1995, pp. 692-700.

[18] László Gáspár: Management aspects of road pavement rehabilitation. Gradevinar 1/2017, pp. 31-40. DOI: http://doi.org/dpbt

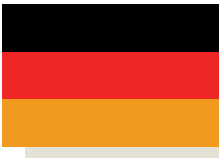

\section{Die Eigentümlichkeiten des städtischen Fahrbahnmanagements}

Das für die Budapest Közút Zrt. (die für das Management der Strassen in Budapest zuständige Gesellschaft) kürzlich als Weiterentwicklung der ersten, vor 8 Jahren entwickelten System erstellte Fahrbahnmanagementsystem (PMS) ist im wesentlichen netzwerkbasiert. Es wurden jedoch auch detailliertere PMS-Grundsätze auf der Projekt(Einrichtung)-Ebene festgelegt. Das neue Fahrbahnmanagementsystem ist deutlich besser als bisher geeignet für die - in Anbetracht der zahlreichen Beeinflussungsfaktoren und Wechselwirkungen - zuverlässigere Erstellung der kurz- und mittelfristigen Fahrbahnerneuerungsstrategien der Budapester Közút Zrt. 